\title{
Channel morphodynamics on a small proglacial braid plain (Fagge River, Gepatschferner, Austria)
}

\author{
DAVID MORCHE ${ }^{1,2}$, ANNE SCHUCHARDT ${ }^{1}$, KAROLIN DUBBERKE $^{1} \&$ \\ HENNING BAEWERT ${ }^{1}$
}

1 Institute for Geosciences and Geography, Martin-Luther-University Halle-Wittenberg, D-06099 Halle/Saale, Germany david.morche@geo.uni-halle.de

2 Catholic University of Eichstaett-Ingolstadt, Department of Physical Geography, Ostenstr.18, D-85072 Eichstaett, Germany

\begin{abstract}
Braid plains are important sediment stores in high mountains, particularly in the glacier forefields of Alpine glaciers. Proglacial braid plains receive sediment input from glacial meltwater and proglacial sediment sources like moraines and glacio-fluvial deposits. The channel morphodynamics on the braid plains are strongly related to the sediment transport and flow regime of the proglacial river. This study deals with channel morphodynamics on a small proglacial braid plain in the European Alps. It focuses on two different time scales. Decadal channel planform changes were assessed by remote sensing approaches. The recent channel bed changes were investigated by cross-sectional surveys and particle counts in 2013. This study is part of the DFG/FWF funded interdisciplinary research project PROSA (High-resolution measurements of morphodynamics in rapidly changing PROglacial Systems of the Alps).
\end{abstract}

Key words proglacial braid plain; channel morphodynamics; planform changes; grain size; Kaunertal, Austria

\section{INTRODUCTION}

Braid plains are important landforms in summit regions of the world particularly, in glacier forefields of Alpine glaciers (Geilhausen et al. 2012a, Geilhausen et al. 2012b). Braid plains develop in alluvial channel reaches or upstream of barriers and are key parameters in the sediment budget (Maizels 1979, Warburton 1990). They can switch their role from sediment sinks, when more sediment is deposited than eroded, to sediment sources, when erosion dominates (Bimböse et al. 2011). Proglacial braid plains receive sediment input from glacial melt water and proglacial sediment sources like moraines and glacio-fluvial deposits. The channel morphodynamics on proglacial braid plains are strongly related to the sediment transport and flow regime of the river draining the upstream glacier (Warburton 1992, 1994, Stott 2002, Luchi et al. 2007,). Recently, Marren \& Toomath (2014) highlighted that topographic forcing in deglaciating areas is associated with channel pattern change.

The interdisciplinary research project PROSA (High-resolution measurements of morphodynamics in rapidly changing PROglacial Systems of the Alps) investigates the sediment budget of a proglacial system in the European Alps combining various methods for different geomorphological processes (Heckmann et al. 2012). For example, debris flows are quantified by terrestrial laser-scanning and modelled (Haas et al. 2012). Sediment transport in the main channel is measured (Morche et al. 2012). In this context, several river reaches are observed by terrestrial laser-scanning in order to quantify sediment erosion and deposition along the channel course (Baewert \& Morche 2014). So far, Baewert \& Morche (2014) have identified braid plains acting as net sediment stores. In this study the focus is on channel morphodynamics on a small braid plain. The main objectives are to

(1) analyse the channel pattern changes over four decades (1969-2010) using remote sensing approaches and available discharge data, and

(2) characterize the channel bed changes and grain size and grain shape characteristics of the channel bed material in the observation period 2013 based on field work.

\section{STUDY AREA}

The Kaunertal valley is located in the European Alps in Tyrol/Austria (Fig. 1(a)). It is drained by the Fagge River (Morche et al. 2012). At the end of the catchment the TIWAG (Tiroler Wasserkraft AG) operates a reservoir. At the inflow of the Fagge River into the reservoir the 
catchment size is $62.5 \mathrm{~km}^{2}$. About $31 \%$ of the catchment is covered by glaciers. The largest glacier in the catchment is the Gepatschferner. This glacier has "retreated" more than $2.5 \mathrm{~km}$ since the end of the little ice age (LIA) at around 1850. The braid plain, we focus on in this study, was completely covered by the Gepatschferner until the 1950s. Giese (1963, profile C in his Fig. 7) carried out detailed refraction seismic surveys on the tongue of the glacier. He observed a sediment filled subglacial basin at the position of the braid plain. On both valley sides, moraine covered bed rock confines the braid plain. A recent geological map shows that the bed rock consists of Paragneiss (Vehling et al. 2013). In 2010, the braid plain had a mean width of $60 \mathrm{~m}$ and a length of about $350 \mathrm{~m}$. The channel bed gradient on the braid plain is $3.8 \%$ (Baewert \& Morche 2014). The TIWAG record discharge every $15 \mathrm{~min}$ at the gauging station Gepatschalm, located $1800 \mathrm{~m}$ downstream of the braid plain (Fig. 1(b)). Discharge data is available from 1971 to present. Haas et al. (2012) observed sediment input to the braid plain by rainstorm-triggered debris flows in 2011. Pre- and post-event terrestrial laser-scans were used to quantify the volume of the transported sediment. The total amount of material delivered from the LIA-moraines during this event was about $1000 \mathrm{~m}^{3}$. Baewert \& Morche (2014) also used laser-scan-based digital elevation models to determine a net sediment accumulation of $8000 \mathrm{~m}^{3}$, mainly caused by a high-magnitude flood in August 2012. During the first field trips in 2013, the whole catchment was covered by a fresh snow cover up to $80 \mathrm{~cm}$ thick.

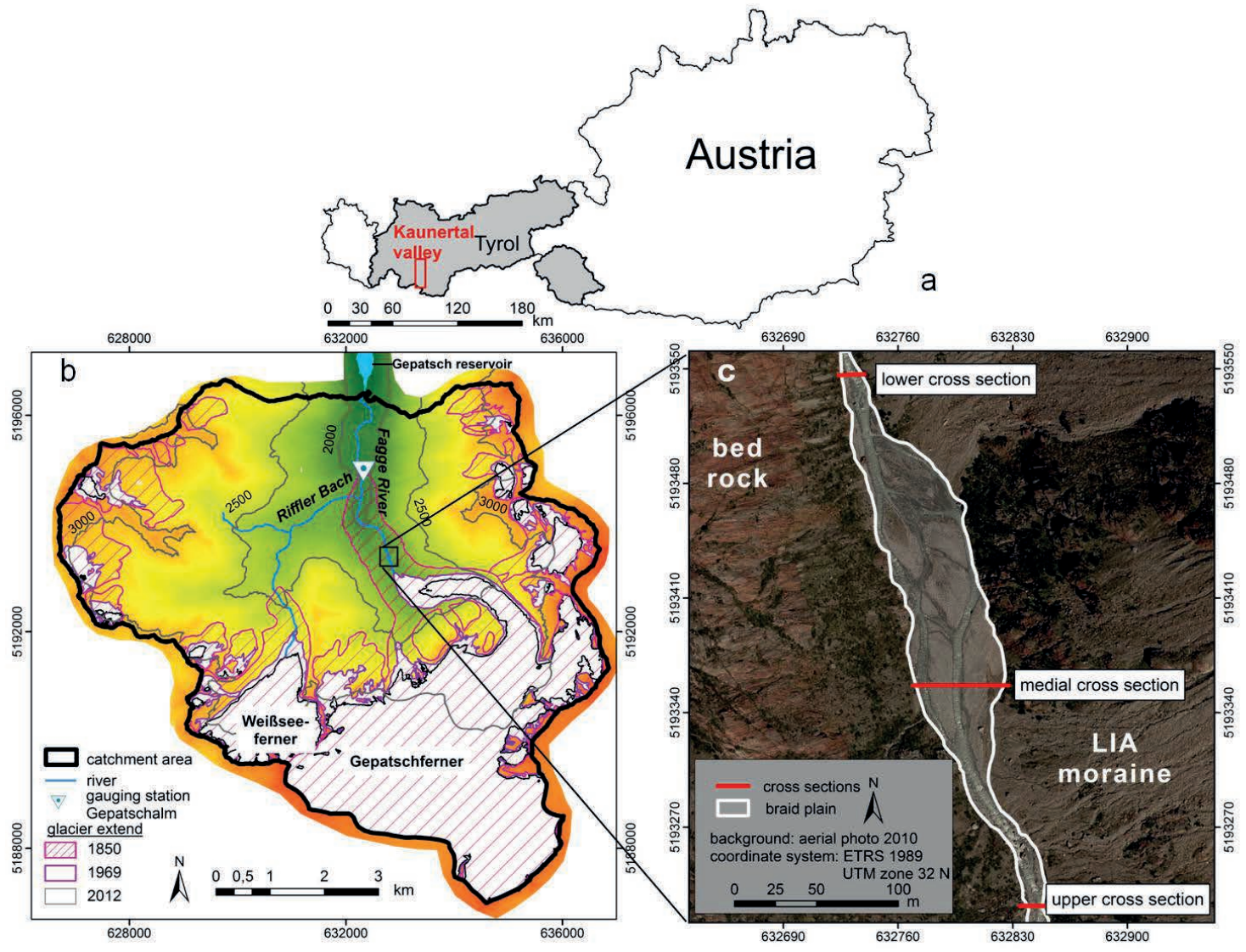

Fig. 1 (a) Location of the study area Kaunertal valley in Austria, (b) the location of the braid plain in the Kaunertal valley, and (c) the braid plain on the orthophoto 2010 and the cross-sections locations.

At the beginning of June 2013 small snow melt-induced debris flows in the LIA-moraines on the right valley side of the braid plain were observed (www.youtube.com/watch? $v=$ EL1LSTWNZOA\&list $=$ HL1370507139\&feature $=$ mh_lolz). These debris flows built up small debris cones on the braid plain at the foot of the moraine slope, a few meters upstream of our medial cross section (Fig. 1(c)). The small debris cones were eroded by subsequent melt water floods. This state of the braid plain was the baseline for our field work in summer 2013. 


\section{MATERIALS AND METHODS}

Channel morphodynamics of the braid plain were investigated using remote sensing and field work approaches. Aerial photographs and orthophotos were used to map the planform changes of the Fagge River over the last four decades. For every time step, river planform characteristics were calculated. Cross-section surveys and particle counts were carried out in the 2013 observation period.

\section{Remote sensing}

To analyse the long-term changes of the proglacial Fagge River orthophotos and discharge measurements were used. To determine the planform changes of the last 40 years, photographs of nine time steps were available. Aerial photography was provided by the Federal Office for Metrology and Surveying in Austria (1969, 1970, 1979, 1982, 1990 and 1997) and by the TIWAG (2003, 2009 and 2010). The older data sets are panchromatic photographs, whereas the photographs provided by TIWAG are multispectral (red-green-blue) recordings. Based on the shading of trees and a solar altitude simulator (Hofmann, 2014) the exact time of recording was calculated for each photograph. Afterwards, this time was linked to the corresponding discharge measured at gauging station Gepatschalm. An overview of all datasets, including the ground and spectral resolution as well as the corresponding discharge, is given in Table 1.

Table 1 Orthophoto meta data; spectral resolution is the number of bands. 1 is panchromatic and 3 is multispectral (red-green-blue); discharge data were recorded at gauging station Gepatschalm (operated by TIWAG).

\begin{tabular}{lllll}
\hline Photo date & Time & $\begin{array}{l}\text { Ground resolution } \\
(\mathrm{m})\end{array}$ & $\begin{array}{l}\text { Spectral resolution } \\
(\text { number of bands })\end{array}$ & $\begin{array}{l}\text { Discharge } \\
\left(\mathrm{m}^{3} \mathrm{~s}^{-1}\right)\end{array}$ \\
\hline $7 / 10 / 1969$ & $11: 00 \mathrm{am}$ & 0.45 & 1 & no data \\
$29 / 9 / 1970$ & $12: 15 \mathrm{pm}$ & 0.20 & 1 & no data \\
$14 / 8 / 1979$ & $10: 30 \mathrm{am}$ & 0.55 & 1 & 4.73 \\
$14 / 9 / 1982$ & $02: 30 \mathrm{pm}$ & 0.50 & 1 & 6.04 \\
$10 / 10 / 1990$ & $11: 00 \mathrm{am}$ & 0.50 & 1 & 1.27 \\
$11 / 9 / 1997$ & $09: 00 \mathrm{am}$ & 0.50 & 1 & 3.44 \\
$5 / 9 / 2003$ & $11: 30 \mathrm{am}$ & 0.20 & 3 & 2.49 \\
$9 / 9 / 2009$ & $11: 30 \mathrm{am}$ & 0.20 & 3 & 2.34 \\
$31 / 7 / 2010$ & $11: 00 \mathrm{am}$ & 0.20 & 3 & 2.92 \\
\hline
\end{tabular}

First, the left and right banks of each channel were digitized. The centreline of a channel was interpolated using the bank lines and the Planform Statistics Tool (Lauer \& Parker, 2008). Additionally, the braid plains were digitized based on colour differences. In comparison to adjacent bed rock and moraines, the braid plains are characterized by a light greyish colour. For the determination of channel changes different parameters were used. The length of the main channel corresponds to the length of the centreline. The mean width of the main channel was calculated by using the Planform Statistics Tool (Lauer \& Parker, 2008). The sinuosity is defined as the ratio of the channel length and the shortest distance between the starting point of a channel reach and its ending point (Mueller, 1968). For the analysis of braiding two indices were calculated, the total sinuosity and the channel count index (C.I.). These are the most commonly used indices for the characterization of the braiding intensity (Egozi \& Ashmore, 2008). The total sinuosity is the sum of the mid channel lengths of all the segments in a channel reach, divided by the length of the main channel (Friend \& Sinha, 1993). The channel count index determination is based on Howard et al. (1970). According to Howard (1970) the braid plain channel reach was divided into 32 sections. The width of the sections is twice the mean width of the main channel in 2010. In order to ensure the comparability, the section width stays the same for all time steps. Afterwards the number of nodes within a section was counted. The channel count index is the ratio of all nodes within a section and the number of sections. The distance to the glacier, the length of the Fagge River between glacier snout and the beginning of the braid plain channel reach, was also mapped for each year. 


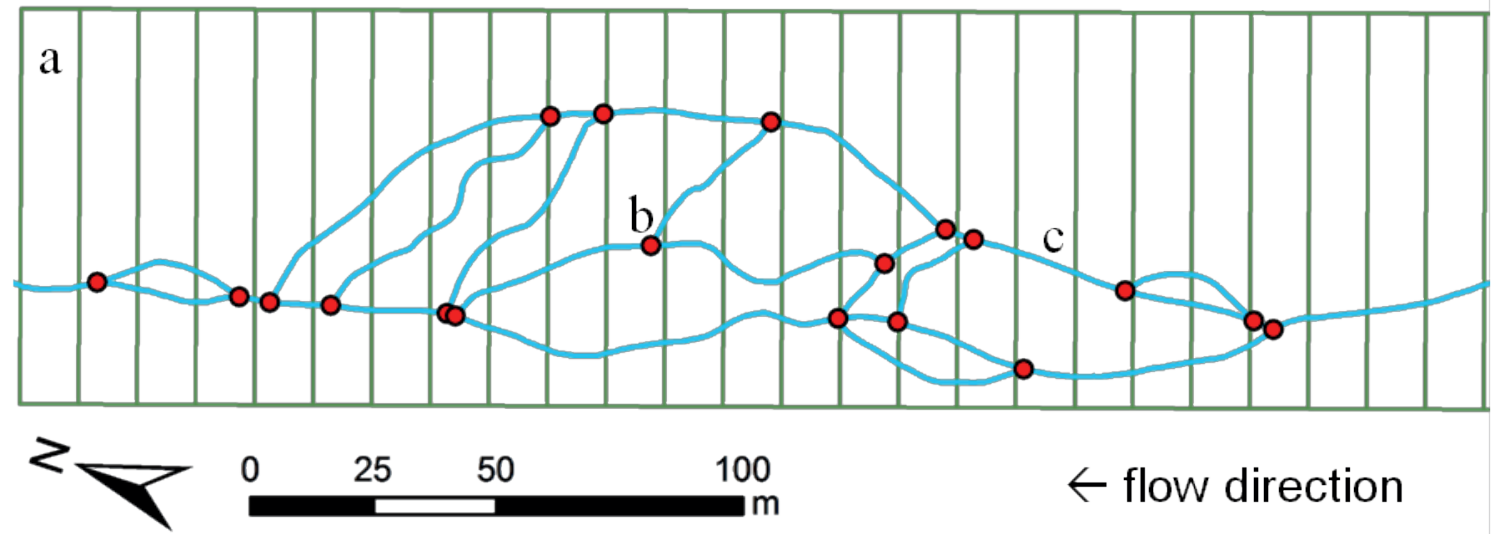

Fig. 2 Analysis of sections for the Channel Count Index; the figure shows the channel pattern on the braid plain in $2010, \mathrm{a}=$ section, $\mathrm{b}=$ node, $\mathrm{c}=$ channel segment.

\section{Field work}

Cross-sections, grain size and grain shape analysis Three cross-sections were surveyed to investigate the recent changes of the channel course and grain size distribution on the braid plain. The upper and lower cross-sections are located at the beginning and the end of the braid plain. The medial cross section is located at the beginning of bed rock outcrop at the right valley side (Fig. 3). Due to high discharges in summer, the profiles were fixed on bedrock. The control points of the beginning and end of the cross-section were levelled using a Trimble dGPS. The cross-sections were measured on 11 June and 2 September in 2013. The depth was measured at $50 \mathrm{~cm}$ intervals along a tensioned tape. Each cross-section survey was complemented by a particle count according to Wolman (1954).
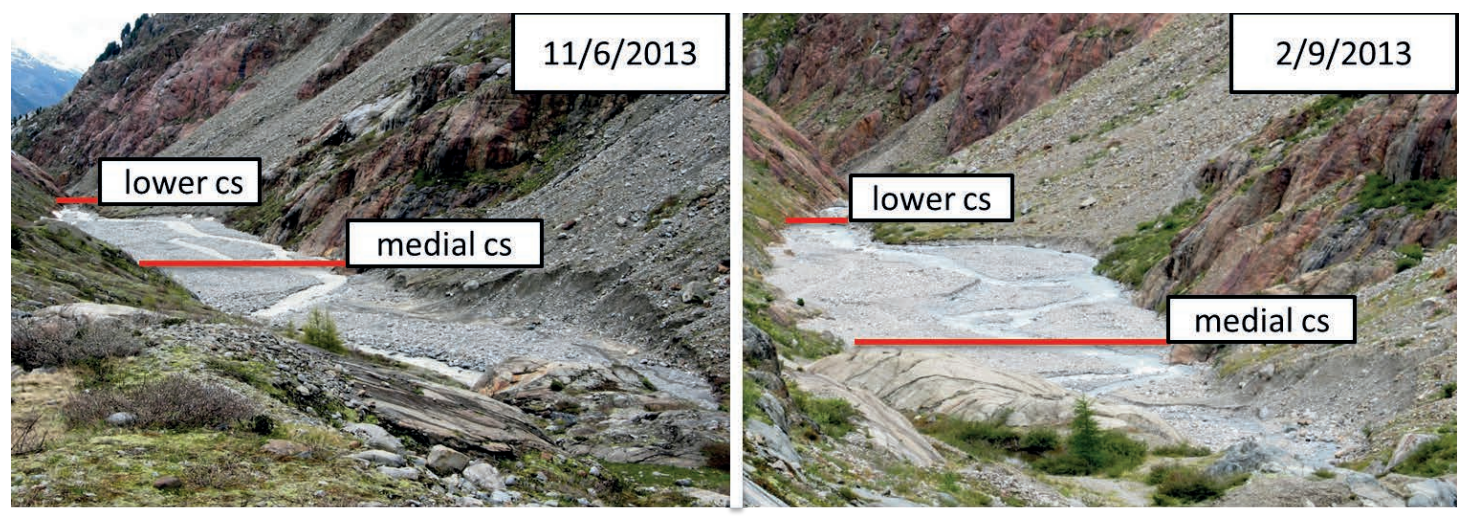

Fig. 3 Location of the cross-sections (cs) on the braid plain; left photo from 11/6/2013 with discharge $3.31 \mathrm{~m}^{3} \mathrm{~s}^{-1}$; right photo from 2/9/2013 with discharge $2.87 \mathrm{~m}^{3} \mathrm{~s}^{-1}$ (view downstream). Discharge is measured at the TIWAG gauging station downstream, see Fig. 1.

About 100 particles were sampled at each cross section and the longest, mean and shortest axis of each particle was measured. The particle analysis includes analysis of size and shape. The b-axis represents the size of each particle. Particle shape characteristics were determined by using the triangular shape diagram of Sneed \& Folk (1958). To determine the particle shape class a modified version of the Tri-Plot software developed by Graham \& Midgley (2000) was used.

\section{RESULTS AND DISCUSSION}

Decadal channel planform changes Channel planforms were mapped for each year with available orthophotos. The changes are shown in a detail in Fig. 4. 


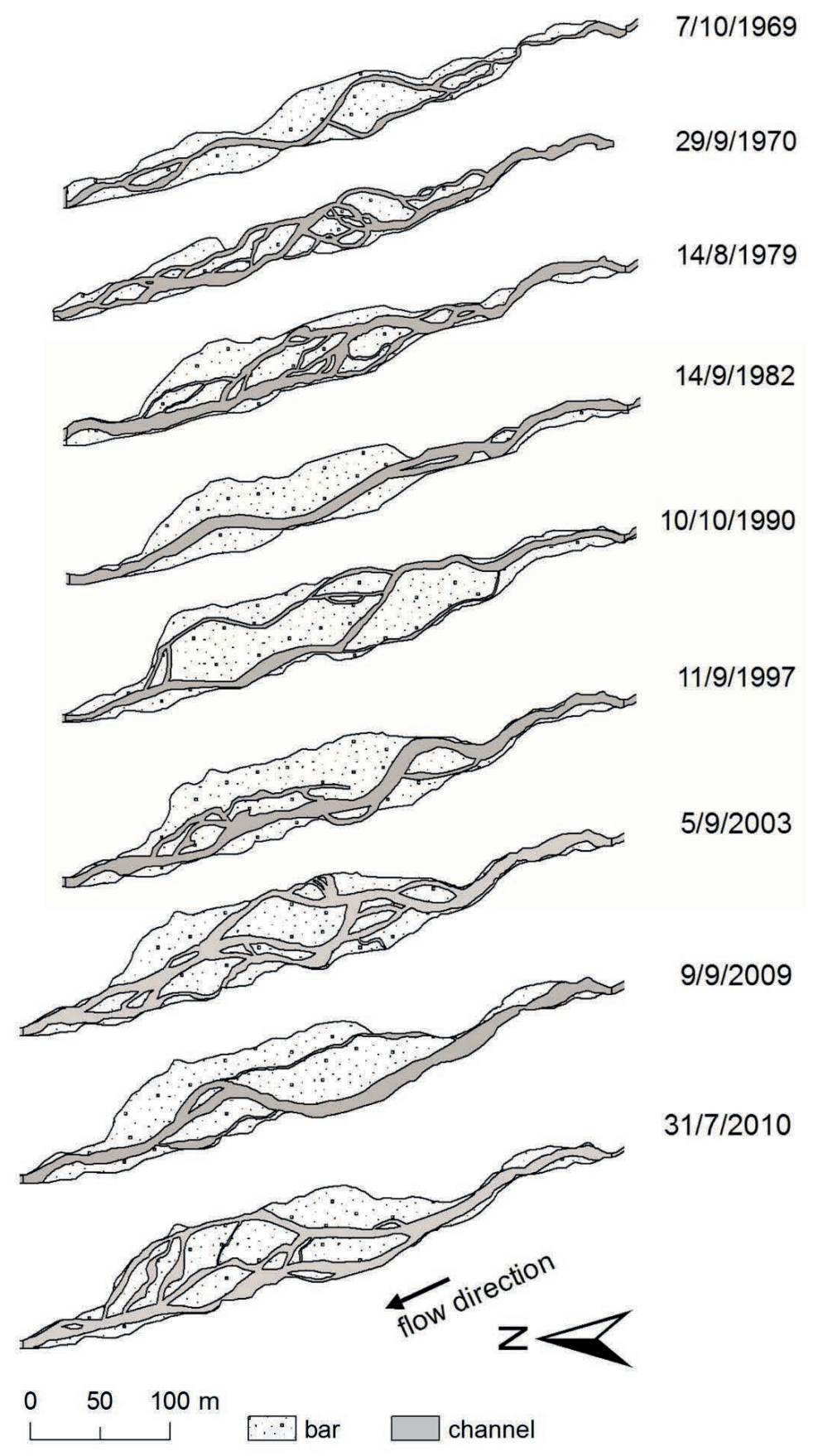

Fig. 4 Channel planform changes on the braid plain from 1969 to 2010.

Depending on the discharge and sediment availability different channel patterns develop on the braid plain. The average width of the channel changed over the last four decades. Sediment reworking occurred on the adjacent LIA-moraines. On the aerial photographs, this is visible by debris flows and slip-edges. Due to the permanent switch of the channel bed there is a cut-off of the lateral moraines. Furthermore, debris flows can cause the displacement of the channel. Thus, different widths and extents of the braid plain were recognized. Especially on the older aerial photographs, the braid plain was considerably narrower. Based on the distance to the glacier it is shown that there was glacier advance and glacier retreat in the last 40 years. Between 1969 and 
1979 the glacier was retreating. Then, until 1990 there was a glacier advance. Since the 1990s the Gepatschferner has been characterized by heavy mass loss. Due to this, subglacial sediments have become ice-free. These sediments are unconsolidated and unvegetated and, therefore, are very erodible. The length of the main channel and sinuosity are subject to constant changes during the investigation period. The mean channel width corresponds with the measured discharge. With increasing discharge, the channel widens (see also Smith et al., 1996; Asmore \& Sauks, 2010). The braiding indices are related to the propagation potential on the braid plain and sediment availability. In 2003, the highest braiding indices were calculated. In 1969, the lowest values were calculated. Considering the whole period of investigation, no clear trends are apparent. Egozi \& Ashmore (2008) stated that the braiding intensity increases up to a certain discharge. With a further increase the braiding intensity decreases.

Table 2 Results of the channel planform analyses.

\begin{tabular}{|c|c|c|c|c|c|c|c|}
\hline \multirow[t]{2}{*}{ Date } & \multirow{2}{*}{$\begin{array}{l}\text { Length main } \\
\text { channel }(\mathrm{m})\end{array}$} & \multirow{2}{*}{$\begin{array}{l}\text { Mean width } \\
\text { main } \\
\text { channel (m) }\end{array}$} & \multirow{2}{*}{$\begin{array}{l}\text { Sinousity } \\
\text { main } \\
\text { channel }\end{array}$} & \multicolumn{2}{|c|}{ Braiding index } & \multirow{2}{*}{$\begin{array}{l}\text { Total no. of } \\
\text { channel } \\
\text { segments }\end{array}$} & \multirow{2}{*}{$\begin{array}{l}\text { Distance } \\
\text { to glacier } \\
\text { (m) }\end{array}$} \\
\hline & & & & $\begin{array}{l}\text { Total } \\
\text { sinuosity }\end{array}$ & $\begin{array}{l}\text { Channel } \\
\text { count index }\end{array}$ & & \\
\hline $7 / 10 / 1969$ & 415 & 2.9 & 1.10 & 1.55 & 0.19 & 10 & 118 \\
\hline 29/9/1970 & 408 & 4.8 & 1.08 & 2.64 & 1.31 & 46 & 153 \\
\hline 14/8/1979 & 407 & 5.8 & 1.08 & 2.53 & 1.15 & 37 & 250 \\
\hline 14/9/1982 & 395 & 6.3 & 1.04 & 1.28 & 0.21 & 7 & 212 \\
\hline 10/10/1990 & 406 & 4.5 & 1.06 & 2.74 & 0.50 & 16 & 189 \\
\hline $11 / 9 / 1997$ & 405 & 6.8 & 1.07 & 1.93 & 0.50 & 16 & 282 \\
\hline $5 / 9 / 2003$ & 406 & 5.7 & 1.07 & 2.75 & 1.12 & 36 & 541 \\
\hline 9/9/2009 & 400 & 6.1 & 1.05 & 1.93 & 0.38 & 12 & 772 \\
\hline $31 / 7 / 2010$ & 394 & 5.6 & 1.04 & 2.07 & 0.84 & 27 & 823 \\
\hline
\end{tabular}

Recent channel bed changes Channel changes at all three cross-section locations were recognized between June and September 2013. The upper cross-section showed the smallest changes. A mid channel bar was relocated to the right channel side while the depth, width and cross-sectional area almost stayed constant (Fig. 5 and Table 3). The medial cross-section showed an accumulation at the central part and slight erosion at the right channel side. The cross-sectional area has decreased from 83 to $74.6 \mathrm{~m}^{2}$, which indicates a net accumulation of $8.2 \mathrm{~m}^{2}$. Therefore, the width-to-depth ratio increased. The lower cross-section showed an increase of channel width and a concentration of the channel on the right side. On the left side the formation of a central bar is observed. In total, the entire cross-sectional area stayed constant. While, at the left side there was an accumulation of $2.5 \mathrm{~m}^{2}$, almost the same amount of material was eroded on the right side. The whole braid plain area is as active as in the decades before (see above) and is strongly influenced by proglacial processes. The braid plain acts as a short term store for coarse material and turns rapidly into a sediment source during subsequent floods. This result was also shown by Baewert \& Morche (2014) for a high-magnitude flood in 2012. Furthermore, changes of the cumulative frequency distribution of grain sizes were recognized. For all three cross-sections a finer particle size distribution was detected in September 2013. It is also remarkable that the upper 10\% to $20 \%$ of the sampled material is coarser than the material in June. In September the bed material was less sorted than in June. The shape distribution is dominated by bladed and elongate particles.

Table 3 Characteristic channel cross section parameters and grain sizes.

\begin{tabular}{|c|c|c|c|c|c|c|c|c|c|c|c|c|c|}
\hline \multirow[t]{2}{*}{$\begin{array}{l}\text { Cross- } \\
\text { section }\end{array}$} & \multirow{2}{*}{$\begin{array}{l}\text { Distance } \\
\text { to glacier } \\
\text { (m) }\end{array}$} & $\begin{array}{l}\text { Width } \\
\text { (m) }\end{array}$ & $\begin{array}{l}\text { Depth }_{m} \\
\text { (m) }\end{array}$ & $\begin{array}{l}\text { Area } \\
\left(\mathrm{m}^{2}\right)\end{array}$ & $\mathrm{w} / \mathrm{d}_{\mathrm{m}}$ & $\begin{array}{l}\mathrm{D}_{16} \\
(\mathrm{~mm})\end{array}$ & $\begin{array}{l}\mathrm{D}_{84} \\
(\mathrm{~mm})\end{array}$ & $\begin{array}{l}\text { Width } \\
\text { (m) }\end{array}$ & $\begin{array}{l}\text { Depth } \\
\text { (m) }\end{array}$ & $\begin{array}{l}\text { Area } \\
\left(\mathrm{m}^{2}\right)\end{array}$ & $\mathrm{w} / \mathrm{d}_{\mathrm{m}}$ & $\begin{array}{l}\mathrm{D}_{16} \\
(\mathrm{~mm})\end{array}$ & $\begin{array}{l}\mathrm{D}_{84} \\
(\mathrm{~mm})\end{array}$ \\
\hline & & \multicolumn{6}{|c|}{ Cross-section June 2013} & \multicolumn{6}{|c|}{ Cross- section September 2013} \\
\hline Upper & 1946 & 24.5 & 1.63 & 40.36 & 15.03 & 25 & 112 & 24.5 & 1.65 & 40.85 & 14.85 & 21 & 114 \\
\hline Medial & 2063 & 59.7 & 1.38 & 83.01 & 43.57 & 37 & 125 & 60 & 1.23 & 74.60 & 48.78 & 16 & 118 \\
\hline Lower & 2280 & 16.6 & 0.92 & 16.06 & 17.84 & 30 & 127 & 18.4 & 0.85 & 16.37 & 21.65 & 19 & 118 \\
\hline
\end{tabular}




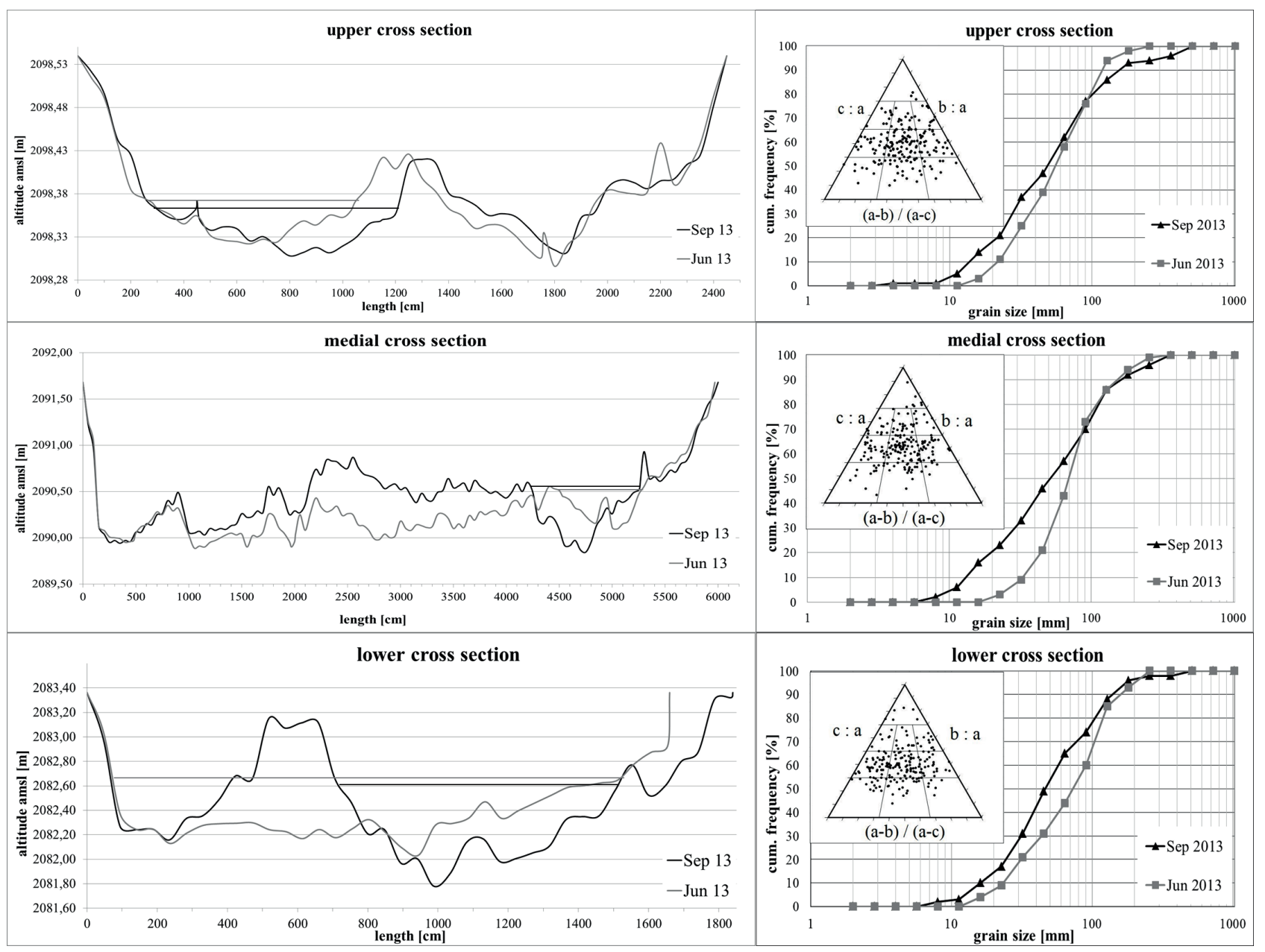

Fig. 5 Cross-section profiles and cumulative frequency distribution of particle count samples from June and September 2013. The stage during the cross-section surveys is presented as a grey line (June 2013) and black line (September 2013).

The particle size characteristics show no clear downstream variation (Table 3). Frequent lateral sediment supply by debris flows and deposition of fine material over the summer avoid a clear downstream pattern (e.g. fining) of grain sizes on the braid plain.

\section{CONCLUSIONS AND OUTLOOK}

Channel morphodynamics on recent and decadal time scales were investigated on a small proglacial braid plain in the Kaunertal valley in Austria. The channel planform pattern on the braid plain changed over the last four decades (1969-2010). The main channel migrated over the braid plain. The plain itself showed increase in area mainly during glacial advances in the 1980s. Recent surveys of three cross-sections on the braid plain indicated no clear trend in any downstream pattern (e.g. fining, sorting) of channel bed particles. In the next steps of investigation we will use the braid plain area as a test site for terrestrial laser-scanning assessment of surface roughness changes in relation to diurnal, seasonal and annual sediment transporting events.

Acknowledgements This study is supported by the German Research Foundation (DFG, grant reference numbers MO 2068/3-1, FR 867/26-2, BE1118/30-2). We thank our undergraduate and graduate students Martin Weber and Matthias Faust, and the DAAD research interns Shannon Hibbard and Halil Basburg for assistance during field and lab work. The company TIWAG kindly provided 2013 discharge data and orthophotos. 


\section{REFERENCES}

Ashmore, P. \& Sauks, E. (2006) Prediction of discharge from water surface width in a braided river with implications for at-astation hydraulic geometry. Water Resources Research 42(3): W03406. doi: 10.1029/2005WR003993.

Baewert, H. \& Morche, D. (2014) Coarse sediment dynamics in a proglacial fluvial system (Fagge River, Tyrol). Geomorphology. doi: 10.1016/j.geomorph.2013.10.021

Bimböse, M., et al. (2011) Investigations on intra- and interannual coarse sediment dynamics in a high-mountain catchment. Zeitschrift für Geomorphologie N F. 55 Supplementary Issue 2, 67-81. doi:10.1127/0372-8854/2011/0055S2-0046.

Egozi, R. \& Ashmore, P. (2008) Defining and measuring braiding intensity. Earth Surface Processes and Landforms 33(14), 2121-2138. doi: 10.1002/esp.1658.

Friend, P.F. \& Sinha R. (1993) Braiding and meandering parameters. In: Braided Rivers (ed. by Best, J.L. \& Bristow, C.S.) 105-112, The Geological Society, London.

Geilhausen, M., et al. (2012a): Decadal sediment yield from an Alpine proglacial zone inferred from reservoir sedimentation (Pasterze, Hohe Tauern, Austria). In: Erosion and Sediment Yields in the Changing Environment (ed. by A.L. Collins, et al.), IAHS Publ. 356, 161-172. IAHS Press, Wallingford, UK.

Geilhausen, M., Otto, J.-C. \& Schrott, L. (2012b) Spatial distribution of sediment storage types in two glacier landsystems (Pasterze \& Obersulzbachkees, Hohe Tauern, Austria). Journal of Maps 8(3), 24--259. doi: 10.1080/17445647.2012.708540

Graham, D.J. \& Midgley, N.G. (2000) Graphical representation of particle shape using triangular diagrams: an Excel spreadsheet method. Earth Surface Processes and Landforms 25(13), 1473-1477.

Haas, F. et al. (2012) Quantification and modelling of debris flows in the proglacial area of the Gepatschferner/Austria using ground-based LiDAR. In: Erosion and Sediment Yields in the Changing Environment (ed. by A.L. Collins, et al. ), IAHS Publ. 356, 293-302. IAHS Press, Wallingford, UK.

Heckmann, T., et al. (2012) Investigating an alpine proglacial sediment budget using field measurements, airborne and terrestrial LiDAR data. In: Erosion and Sediment Yields in the Changing Environment (ed. by A.L. Collins, et al. ), IAHS Publ. 356, 438-447. IAHS Press, Wallingford, UK.

Hoffmann,T. (2014) Sonnenverlauf. available from http://www.sonnenverlauf.de (27/01/2014)

Howard, A.D., Keetch, M.E. \& Vincent, C.L. (1970) Topological and geometrical properties of braided streams. Water Resources Research 6(6): 1674-1688. doi: 10.1029/WR006i006p01674.

Lauer, J. \& Parker, G. (2008) Net local removal of floodplain sediment by river meander migration. Geomorphology 96(1-2): 123-149. doi: 10.1016/j.geomorph.2007.08.003.

Luchi, R., et al. (2007) Monitoring and predicting channel change in a free-evolving, small Alpine river: Ridanna Creek (North East Italy). Earth Surface Processes and Landforms 32(14), 2104-2119.

Maizels, J.K. (1979) Proglacial aggradation and changes in braided channel patterns during a period of glacier advance: an Alpine example. Geografiska Annaler A 61, 87-101.

Marren, P.M. \& Toomath, S.C. (2013) Fluvial adjustments in response to glacier retreat: Skaftafellsjökull, Iceland. Boreas 42(1), 57-70. doi: 10.1111/j.1502-3885.2012.00275.x.

Marren, P.M. \& Toomath, S.C. (2014) Channel pattern of proglacial rivers: topographic forcing due to glacier retreat. Earth Surface Processes and Landforms. doi: 10.1002/esp.3545

Morche, D., et al. (2012) Sediment transport in the proglacial Fagge River (Kaunertal/Austria). In: Erosion and Sediment Yields in the Changing Environment (ed. by A.L. Collins, et al. ), IAHS Publ. 356, 72-80. IAHS Press, Wallingford, UK

Mueller, J. (1968) An introduction to the hydraulic and topographic sinuosity indexes 1. Annals of the Association of American Geographers 58(2), 371-385. doi: 10.1111/j.1467-8306.1968.tb00650.x.

Smith, L.C., et al. (1996) Estimation of discharge from three braided rivers using synthetic aperture radar satellite imagery: potential application to ungaged basins. Water Resources Research 32(7), 2021-2034. doi: 10.1029/96WR00752.

Graham, D.J. \& Midgley, N.G. (2000) Graphical representation of particle shape using triangular diagrams: an Excel spreadsheet method. Earth Surface Processes and Landforms 25(13), 1473-1477.

Sneed, E.D. \& Folk, R.L. (1958) Pebbles in the lower Colorado River, Texas: A study in particle morphogenesis. Journal of Geology 66, 114-150.

Stott, T. (2002) Bedload transport and channel bed changes in the proglacial Skeldal River, northeast Greenland. Arctic, Antarctic, and Alpine Research 34(2), 334-345

Vehling, L., Rohn, J. \& Moser, M. (2013) Gravitative Massenbewegungen in einem proglazialen Geosystem, Gepatschferner, Tirol - Quantitative Erfassung der relevanten Geofaktoren und Bilanzierungsansätze. Veröff. zur 19. Tagung Ingenieurgeologie, München, 470-475.

Warburton, J. (1990) An alpine proglacial fluvial sediment budget. Geografiska Annaler A 72, $261-272$.

Warburton, J., (1992) Observations of bed load transport and channel bed changes in a proglacial mountain stream. Arctic and Alpine Research 3, 195-203.

Warburton, J. (1994) Channel change in relation to meltwater flooding, Bas Glacier d'Arolla, Switzerland. Geomorphology 11, $141-149$

Wolman, M.G. (1954) A method of sampling coarse river-bed material. Transactions of the American Geophysical Union $35(6), 951-956$ 